Е. О. Завьялова

Байкальский государственный университет, г. Иркутск, Российская Федерация

В. И. Завьялов

Байкальский государственный университет, г. Иркутск, Российкая Федерация

\title{
ПОЧЕМУ РЕГИСТРАЦИЯ ОРГАНИЗАЦИЙ В ЖИЛОМ ФОНДЕ ПРЕПЯТСТВУЕТ УВЕЛИЧЕНИЮ ДОХОДОВ БЮДЖЕТА?
}

\begin{abstract}
АННОТАЦИЯ. В статье проводится исследование налоговой задолженности и механизма ее урегулирования. Особое внимание уделяется совместной работе налоговых органов и судебных приставов при взыскании налоговой задолженности. Рассмотрены причины существования налоговой задолженности, выделяемые в экономической литературе. Выявлена еще одна причина наличия налоговой задолженности - регистрация организаций на адресах жилого фонда. Проведен анализ налоговой задолженности и результатов ее взыскания с организаций, зарегистрированных на адресах жилого фонда. Для исследования использовались данные статистической отчетности налоговых органов по формам 4-HМ и 4-OP. Показано, что более половины исполнительных производств $(56,8$ \%), которые судебные приставы возвращают налоговым органам - это дела о взыскании с организаций, зарегистрированных в жилом фонде. Однако задолженность по таким исполнительным производствам остается не взысканной по причине фактического отсутствия организаций по адресам регистрации. Описано законодательное регулирование вопроса регистрации организаций в жилом фонде. Сделан вывод, что установление запрета на регистрацию организаций по определенным видам экономической деятельности в жилом фонде позволит сократить налоговую задолженность перед бюджетом.
\end{abstract}

кЛЮчЕВЫЕ СЛОВА. Доходы бюджета; налоговая задолженность; урегулирование налоговой задолженности; взыскание налоговой задолженности; регистрация организаций; налоговые органы; Федеральная служба судебных приставов.

ИНФОРМАЦИЯ О СТАТЬЕ. Дата поступления 13 июля 2016 г.; дата принятия к печати 26 августа 2016 г.; дата онлайн-размещения 30 сентября 2016 г.

E. O. Zavyalova Baikal State University, Irkutsk, Russian Federation

V. I. Zavyalov Baikal State University, Irkutsk, Russian Federation

\section{WHY REGISTRATION OF ORGANIZATIONS IN THE HOUSING STOCK PREVENTS INCREASE IN BUDGET REVENUES}

\begin{abstract}
The article investigates tax liabilities and the mechanism of their regulation. It pays a special attention to collaboration of tax authorities and bailiffs in collecting tax liabilities. It considers the reasons of existing tax liabilities identified in economic literature, while specifying one more cause of tax liabilities existence, that is, registration of organizations on housing stock addresses. It carries out an analysis of tax liabilities and the results of their collection from organizations registered on housing stock addresses. For research, it uses the statistical reporting data of tax authorities in forms 4-NM and 4-OR. It shows that more than a half of enforcement proceedings $(56,8 \%)$ which bailiffs return to tax authorities are cases of collection
\end{abstract}

\section{Baikal Research Journal}


from the organizations registered in the housing stock. But the tax labilities in such enforcement proceedings remains not collected due to actual absence of organizations in registration addresses. The article describes legislative regulation of the issue of registering organizations in the housing stock and concludes that establishing prohibition on registering certain types of economic activity in the housing stock will allow to reduce budget tax liabilities.

KEYWORDS. Budget revenues; tax liabilities; settlement of a tax liabilities; collection of tax liabilities; registration of organizations; tax authorities; Federal Bailiff Service.

ARTICLE INFO. Received July 13, 2016; accepted August 26, 2016; available online September $30,2016$.

Целью нашего исследования является определение причин стабильного существования и роста налоговой задолженности перед бюджетом Российской Федерации. Поскольку более половины доходов бюджета формируется за счет налоговых поступлений, то взыскание и поступление задолженности по данному виду обязательных платежей имеет важное значение для формирования финансовых ресурсов государства.

Исследование налоговой задолженности является актуальным направлением в экономической литературе. Так, часть авторов рассматривают снижение налоговой задолженности необходимым условием эффективности налогового контроля [1;2]. Большое количество работ посвящено анализу налоговой задолженности. Например, М. Мохтари, С. Кейнер, В. Конторович, рассматривая во взаимосвязи дебиторскую задолженность предприятий, налоговую задолженность и задолженность по заработной плате, в своей работе пришли к выводу, что «неплатежи между предприятиями и задолженность по налогам оказывают влияние на задолженность по заработной плате»[3, с. 8]. Авторами выделены долгосрочные и краткосрочные факторы, способствующие накоплению задолженности, воздействие на которые должно привести к сокращению неплатежей.

При этом изучение состояния налоговой задолженности и его характеристика проводится не только в масштабах страны, но и на уровне федеральных округов, например, Центральный федеральный округ рассматривается в работе Г. Л. Поповой [4], Сибирский федеральный округ представлен в статье Б. Л. Лавровского [5] и т. д. Важное направление исследования налоговой задолженности составляет рассмотрение взыскания задолженности с точки зрения издержек налогообложения как налоговых органов (расходы на оплату труда сотрудников, расходы на содержание и др.), так и налогоплательщиков (например, пени, налоговые штрафы, претензионные расходы при урегулировании споров с налоговыми органами и др.) [6].

Стоит отметить, что при исследовании налоговой задолженности учеными экономистами особое внимание уделяется причинам образования налоговой задолженности. Так, в диссертационных исследованиях А. В. Пироговой [7], Р. И. Шумяцкого [8] можно встретить подробную классификацию причин и факторов роста налоговой задолженности. Однако несмотря на разнообразие классификационных признаков причин возникновения налоговой задолженности, их можно разделить на политические, экономические, психологические, организационные и иные. По мнению авторов, для практического устранения причин налоговой задолженности необходима их конкретизация. Например, Б. Х. Алиев предлагает для борьбы с налоговой задолженностью классифицировать налогоплательщиков по признаку соблюдения налогового законодательства и применять к каждой категории конкретные мероприятия для повышения эффективности администрирования налоговой задолженности [9]. О. А. Бондарь видит причинами существования на-

\section{Baikal Research Journal}

электронный научный журнал Байкальского государственного университета 
логовой задолженности несовершенство института налоговой отсрочки и рассрочки, а также фактическое неприменение обеспечительных форм - залога и поручительства. По мнению автора, залог и поручительство нужно «рассматривать не как обязательный элемент в применении изменения сроков уплаты налогов, т. е. отсрочки, рассрочки. А как самостоятельный метод урегулирования налоговой задолженности» [10, с. 61].

В работе Ф. Ф. Адигамовой существование задолженности, которую невозможно взыскать, объясняется миграцией организаций. Она предлагает ограничить переход организаций из региона в регион на определенный срок (1 год) и затрагивает вопрос о регистрации и учете налоговыми органами организаций. Ф. Ф. Адигамова также делает акцент на существовании адресов массовой регистрации и предлагает создание единой информационной базы о постановке и снятии с учета [11].

Регистрация фирм-однодневок также относится к причинам невозможности взыскания налоговой задолженности, поскольку применение принудительных мер взыскания затруднено отсутствием имущества у таких организаций. Л. С. Кирина, Н. А. Горохова, А. В. Александров предлагают ввести налоговый залог, который должен стать гарантийным депозитом в счет будущих или имеющихся налоговых платежей при регистрации организации. В своей работе авторы приводят пример расчета налогового залога [12, с. 89].

В предыдущих исследованиях не обращалось внимание на еще одну причину, которая, по нашему мнению, является значимой. Это возможность регистрации организаций по адресам, принадлежащим к жилому фонду. Для того чтобы исследовать данную причину, нами была проанализирована налоговая задолженность организаций, зарегистрированных по адресам, принадлежащим к жилому фонду, и поступления в бюджет при ее взыскании.

В настоящее время проблема взыскания задолженности с указанных организаций имеет большое значение, поскольку налоговые органы, произведя все возможные меры по принудительному взысканию, передают должников-организаций в Федеральную службу судебных приставов (ФССП). В свою очередь, ФССП осуществляет исполнительное производство по полученным делам в рамках разового посещения организаций по зарегистрированным адресам жилого фонда. Поскольку законные представители отсутствуют по зарегистрированным адресам, и разыскать их не удается, исполнительное производство прекращается и отправляется обратно налоговым органам. При этом суммы такой налоговой задолженности считаются урегулированными, так как применен весь комплекс действий. Однако по факту в бюджет они не поступают. Налоговые органы не принимают каких-либо дальнейших действий, поскольку показатели оценки их деятельности не ухудшаются, а ФССП считает данные исполнительные производства отработанными. Возникает проблема - все действия совершены, но суммы налоговой задолженности не взысканы.

Далее рассмотрим процесс урегулирования налоговой задолженности и включение в отчетность сумм налоговой задолженности налоговыми органами.

Урегулированная задолженность содержит суммы недоимки, пеней, штрафов, в отношении которых применены все меры принудительного взыскания (табл. 1). В сумму урегулированной задолженности согласно формам статистической отчетности налоговых органов также входит сумма задолженности, прекращенная к взысканию в связи с невозможностью установления местонахождения должника и его имущества (подп. 3 п. 1 ст. 46 Федерального закона «Об исполнительном производстве» № 229-Ф3). В частности, к прекращенной к взысканию относятся суммы урегулированной задолженности организаций, которые зарегистрированы на адресах жилого фонда.

\section{Baikal Research Journal}


Таблица 1

Структура задолженности по налогал и сборам по итогам 2013-2015 22. в Российской Федерации

\begin{tabular}{|c|c|c|c|c|c|c|}
\hline \multirow[t]{2}{*}{ Показатель } & \multicolumn{2}{|l|}{2013} & \multicolumn{2}{|l|}{2014} & \multicolumn{2}{|l|}{2015} \\
\hline & $\begin{array}{c}\text { Задолжен- } \\
\text { ность, тыс. } .\end{array}$ & $\begin{array}{c}\text { Темп } \\
\text { роста, \% }\end{array}$ & $\begin{array}{c}\text { Задолжен- } \\
\text { ность, тыс. } .\end{array}$ & $\begin{array}{c}\text { Темп } \\
\text { роста, \% }\end{array}$ & $\begin{array}{c}\text { Задолжен- } \\
\text { ность, тыс. } . \text {. }\end{array}$ & $\begin{array}{c}\text { Темп } \\
\text { роста, \% }\end{array}$ \\
\hline $\begin{array}{l}\text { Задолженность перед } \\
\text { бюджетом }\end{array}$ & 770308170 & 105,79 & 802681722 & 104,20 & 827344753 & 103,07 \\
\hline $\begin{array}{l}\text { Возможная к взыска- } \\
\text { нию }\end{array}$ & 765337421 & 105,88 & 793643526 & 103,70 & 820517886 & 103,39 \\
\hline В том числе недоимка & 384939461 & 111,17 & 430315931 & 111,79 & 461412247 & 107,23 \\
\hline $\begin{array}{l}\text { Урегулированная за- } \\
\text { долженность }\end{array}$ & 380397960 & 101,02 & 363327595 & 95,51 & 359105639 & 98,84 \\
\hline $\begin{array}{l}\text { Невозможная к взы- } \\
\text { сканию }\end{array}$ & 8139073 & 87,24 & 10969528 & 134,78 & 8728076 & 79,57 \\
\hline Зависшие платежи & 3168324 & 79,51 & 1931332 & 60,96 & 1901209 & 98,44 \\
\hline
\end{tabular}

Составлено по данным Федеральной налоговой службы РФ (форма № 4-НМ «Отчет о задолженности по налогам и сборам, пеням и налоговым санкциям в бюджетную систему РФ»).

Как видно из данных (см. табл. 1), сумма задолженности по налогам и сборам перед бюджетом с 2013 г. в динамике растет. В свою очередь суммы урегулированной задолженности уменьшаются и наблюдаются темпы ее снижения по отношению к предыдущим периодам, несмотря на рост сумм возможной к взысканию задолженности. Данный факт отражает негативное изменение в структуре налоговой задолженности и свидетельствует о снижении эффективности работы с ней. Поэтому имеет смысл исследовать механизм образования и урегулирования задолженности по налогам и сборам.

Механизм урегулирования налоговой задолженности представляет собой систему действий из определенных этапов, закрепленных в Налоговом кодексе РФ (НК РФ). При этом крайняя мера урегулирования задолженности - это применение ст. 47 НК РФ (рис. 1).

После вынесения решения ФССП проводит комплекс мер по установлению должника и его имущества. Если в отведенный срок ФССП не смогла выявить какое-либо имущество должника, то принимается решение о возврате данного дела в налоговый орган в связи с невозможностью определения местонахождения налогоплательщика. Сегодня это распространенная мера прекращения исполнительного производства (табл. 2). Так, в 2014 г. возвращено судебными приставами постановлений в связи с невозможностью взыскания задолженности на сумму 469625 тыс. р., что составило 16,17 \% от общей суммы направленных постановлений о взыскании налогов, сборов, пеней, штрафов за счет имущества должника в соответствии со ст. 47 НК РФ. В динамике суммы задолженности по постановлениям, возвращенным ФССП в связи с невозможностью взыскания, увеличиваются.

Согласно действующему законодательству ФССП в случае невозможности определения местонахождения должника имеют право применять меры по принудительному розыску и приводу должника. К сожалению, на практике данная мера не применяется. Причиной тому видятся высокие временные и финансовые издержки, а также высокая степень загруженности данной службы. Более экономный и выгодный вариант для ФССП - прекратить и вернуть постановления налоговым органам, выполнив свои показатели эффективности деятельности. У налоговых органов суммы задолженности по возвращенным постановлениям относятся к урегулированной задолженности и учитываются при расчете показателей эффективности деятельно-

\section{Baikal Research Journal}

электронный научный журнал Байкальского государственного университета 
сти отделов по урегулированию задолженности инспекций Управления Федеральной налоговой службы. При этом фактически потенциальные поступления от указанных сумм задолженности остаются невзысканными и становятся потерей для бюджета.

\begin{tabular}{|c|c|c|}
\hline \multicolumn{2}{|c|}{$\begin{array}{l}\text { 1. В установленные законодательством сроки оплата } \\
\text { в бюджет не произведена } \\
\end{array}$} & $\begin{array}{c}\text { Не позднее трех месяцев со дня } \\
\text { выявления недоимки. В случае если }\end{array}$ \\
\hline & сумма недоимки и задолженности \\
\hline \multicolumn{2}{|c|}{$\begin{array}{l}\text { 2. Налогоплательщику направляется требование } \\
\text { об уплате налога и сбора }\end{array}$} & $\begin{array}{l}\text { одного года со дня выявления } \\
\text { недоимки п. } 1 \text { ст. } 70 \text { НК РФ }\end{array}$ \\
\hline \multicolumn{2}{|c|}{ 3. Направление требования нал } & \multirow{2}{*}{$\begin{array}{c}\text { В течение } 20 \text { дней с даты вступле- } \\
\text { ния в силу решения, вынесенного } \\
\text { по результатам налоговой проверки } \\
\text { п. } 2 \text { ст. } 70 \text { НК РФ } \\
\end{array}$} \\
\hline$\frac{1}{\nabla}$ & & \\
\hline \multirow{2}{*}{$\begin{array}{c}\text { Передано руководителю } \\
\text { организации (ее законному } \\
\text { или уполномоченному пред- } \\
\text { ставителю) или физическому } \\
\text { лицу (его законному или } \\
\text { уполномоченному представи- } \\
\text { телю) лично под расписку }\end{array}$} & \multirow{2}{*}{\begin{tabular}{|c|} 
При отсутствии возможно- \\
сти вручения лично \\
направляется по почте \\
заказным письмом и \\
считается полученным \\
по истечению шести дней \\
с даты направления письма
\end{tabular}} & \multirow[t]{2}{*}{$\begin{array}{c} \\
\text { Направления налогоплательщику } \\
\text { требования в электронной форме } \\
\text { по телекоммуникационным } \\
\text { каналам связи } \\
\end{array}$} \\
\hline & & \\
\hline \\
\hline \multicolumn{3}{|c|}{$\begin{array}{l}\text { 4. Если требование не исполнено в течение } 8 \text { дней (если более продолжительный период времени } \\
\text { не указан в этом требовании) с даты его получения } \\
\end{array}$} \\
\hline & & $\nabla$ \\
\hline $\begin{array}{l}\text { При отсутствии открытых } \\
\text { расчетных счетов в банке }\end{array}$ & \multirow{2}{*}{\multicolumn{2}{|c|}{$\begin{array}{c}\text { 5. В течение двух месяцев налоговый орган выносит решение } \\
\text { о взыскании налога и сбора, штрафа и пеней и направляет поруче- } \\
\text { ние в банк на списание денежных средств со счета п. } 3, \text { ст. } 46 \text { НК } \\
\text { РФ, Одновременно принимается решение о приостановление } \\
\text { операций по счетам в банке п. } 2 \text {, ст. } 76 \text { НК РФ } \\
\end{array}$}} \\
\hline$\frac{1}{\nabla}$ & & \\
\hline \multirow{2}{*}{$\begin{array}{c}\text { 7. При недостаточности } \\
\text { денежных средств (отсут- } \\
\text { ствии) в течение одного года } \\
\text { после окончания срока испол- } \\
\text { нения требования об уплате } \\
\text { налога и сбора, штрафа и } \\
\text { пеней выносится решение о } \\
\text { взыскании за счет прочего } \\
\text { имущества подп. } 3, \text { п. } 1, \text { ст. } 47 \\
\text { НК РФ }\end{array}$} & \multicolumn{2}{|r|}{$\nabla$} \\
\hline & \multicolumn{2}{|c|}{$\begin{array}{l}\text { 6. Исполнение обязанности банком: } \\
\text { - при взыскании с рублевого счета не позднее одного операционно- } \\
\text { го дня, следующего за днем получения документа; } \\
\text { - при взыскании с валютного счета не позднее двух операционных } \\
\text { дней, следующих за днем получения документа; } \\
\text { - при недостаточности или отсутствии денежных средств на счетах } \\
\text { налогоплательщика (налогового агента) производится взыскание } \\
\text { за счет электронных денежных средств п. } 6, \text { ст. } 46 \text { НК РФ }\end{array}$} \\
\hline \multicolumn{3}{|c|}{$\begin{array}{l}\text { 8. Постановление направляется судебному приставу-исполнителю в электронном виде в течение трех } \\
\text { дней с момента вынесения такого решения подп. 2, П. 1, ст. } 47 \text { НК РФ }\end{array}$} \\
\hline \\
\hline \multicolumn{3}{|c|}{$\begin{array}{l}\text { 9. Исполнительные действия судебный пристав-исполнитель должен совершить в двухмесячный срок } \\
\text { со дня поступления к нему указанного постановления п. 4, ст. } 47 \text { НК РФ, п. } 1 \text { ст. } 36 \text { Федерального } \\
\text { закона «Об исполнительном производстве» № } 229\end{array}$} \\
\hline
\end{tabular}

\section{Рис. 1. Схела урегулирования налоговой задолженности}

В деятельности налоговых органов все чаще встречаются случаи возвращения ФССП постановлений о взыскании задолженности по ст. 47 НК РФ по причине невозможности установить местонахождение должника и выявить наличие имущества организаций, зарегистрированных в жилом фонде. Так, общее количество организаций, имеющих задолженность перед бюджетом по Свердловскому округу г. Иркутска и находящихся на исполнении в ФССП, за 2015 г. составило 4184 , из них зарегистрированных в жилом фонде - 2414 (что составляет более 57 \% от общего количества организаций), и имеющие задолженность перед бюджетом на сумму 109949 тыс. р. (рис. 2).

\section{Baikal Research Journal}


Таблица 2

Диналика сумл задолженности по налогал и сборал в Российской Федерации и Иркутской области в 2012-2014 г2., взыскиваемой по ст. 47 Налогового кодекса РФ

\begin{tabular}{|c|c|c|c|c|c|c|}
\hline \multirow[t]{2}{*}{ Показатель } & \multicolumn{2}{|c|}{2012} & \multicolumn{2}{|c|}{2013} & \multicolumn{2}{|c|}{2014} \\
\hline & $\begin{array}{c}\text { Российская } \\
\text { Федерация }\end{array}$ & $\begin{array}{c}\text { Иркутская } \\
\text { область }\end{array}$ & $\begin{array}{c}\text { Российская } \\
\text { Федерация }\end{array}$ & $\begin{array}{c}\text { Иркутская } \\
\text { область }\end{array}$ & $\begin{array}{c}\text { Российская } \\
\text { Федерация }\end{array}$ & $\begin{array}{c}\text { Иркутская } \\
\text { область }\end{array}$ \\
\hline $\begin{array}{l}\text { Направлено поста- } \\
\text { новлений о взыска- } \\
\text { нии налогов, сборов, } \\
\text { пеней, штрафов за } \\
\text { счет имущества долж- } \\
\text { ника в соответствии } \\
\text { со ст. } 47 \text { НК РФ на } \\
\text { сумму, тыс. р. }\end{array}$ & 214037985 & 3928501 & 222484950 & 3937959 & 201953366 & 2903615 \\
\hline $\begin{array}{l}\text { Возвращено судеб- } \\
\text { ными приставами } \\
\text { постановлений в свя- } \\
\text { зи с невозможностью } \\
\text { установить местона- } \\
\text { хождение должника } \\
\text { на сумму задолженно- } \\
\text { сти, тыс. р. }\end{array}$ & 12303881 & 358979 & 30856659 & 309630 & 27898994 & 469625 \\
\hline $\begin{array}{l}\text { Доля сумм задолжен- } \\
\text { ности по возвращен- } \\
\text { ным исполнитель- } \\
\text { ным производствам } \\
\text { с формулировкой } \\
\text { «невозможно устано- } \\
\text { вить местонахождение } \\
\text { должника» в общей } \\
\text { сумме задолженности, } \\
\text { направленной на взы- } \\
\text { скание в ФССП, \% }\end{array}$ & 5,74 & 9,14 & 13,87 & 7,86 & 13,81 & 16,17 \\
\hline
\end{tabular}

Составлено по данным Федеральной налоговой службы РФ (форма № 4-ОР «Сведения о результатах работы Управлений ФНС России по субъектам Российской Федерации»).

2414 $(57,7 \%)$

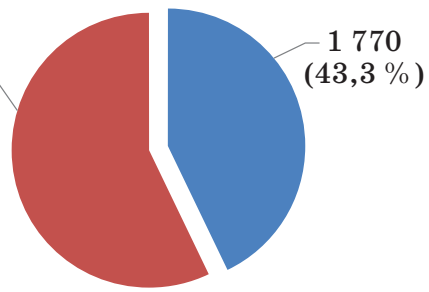

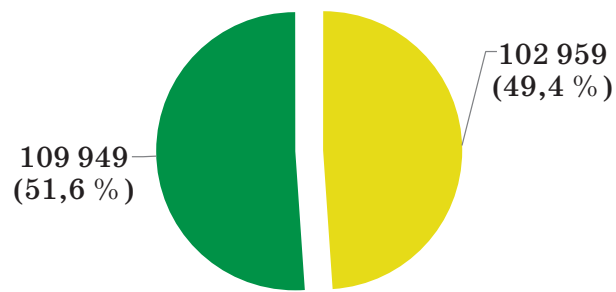

Количество организаций, находящихся на исполнении в ФССП, зарегистрированных на адресах, не относящихся к жилому фонду

— Количество организаций, находящихся на исполнении в ФССП, зарегистрированных на адресах жилого фонда

Сумма задолженности организаций, находящихся на исполнении в ФССП, зарегистрированных на адресах, не относящихся к жилому фонду, тыс. p.

- Сумма задолженности организаций, находящихся на исполнении в ФССП, зарегистрированных на адресах жилого фонда, тыс. p.

Рис. 2. Показатели, характеризующие задолженность организаций в Инспекиии Федеральной налоговой службы по Свердловсколу округу г. Иркутска и находящиеся на исполнении в Федеральной службе судебных приставов в 2015 2.

\section{Baikal Research Journal}


Таким образом, более половины организаций-должников, к которым применены меры по ст. 47 НК РФ, зарегистрированы на адресах жилого фонда. Далее целесообразно рассмотреть результаты исполнения ФССП дел о взыскании: сколько дел возвращается ФССП налоговому органу по причине невозможности установления местонахождения должника, и какую долю в этих делах занимают организации, зарегистрированные в жилом фонде (табл. 3, рис. 3).

Таблица 3

Состояние исполнительных производств по организациям, имеющим задолженность

\begin{tabular}{|l|r|r|r|r|}
\hline \multicolumn{1}{|c|}{ Показатель } & \multicolumn{2}{|c|}{$\begin{array}{c}\text { Количество } \\
\text { организаций }\end{array}$} & \multicolumn{2}{|c|}{$\begin{array}{c}\text { Сумма } \\
\text { задолженности }\end{array}$} \\
\cline { 2 - 5 } & шт. & $\begin{array}{l}\text { Удельный } \\
\text { вес, \% }\end{array}$ & тыс. р. & $\begin{array}{l}\text { Удельный } \\
\text { вес, \% }\end{array}$ \\
\hline $\begin{array}{l}\text { Общее количество организаций, находящихся на ис- } \\
\text { полнении в Федеральной службе судебных приставов }\end{array}$ & 4184 & 100 & 212908 & 100,0 \\
\hline Фактически поступило в бюджет & 525 & 12,6 & 8041 & 3,8 \\
\hline $\begin{array}{l}\text { Находится на исполнении в Федеральной службе } \\
\text { судебных приставов }\end{array}$ & 2918 & 69,7 & 182093 & 85,5 \\
\hline $\begin{array}{l}\text { Возвращено постановлений Федеральной службы } \\
\text { судебных приставов по организациям по причине не- } \\
\text { возможности установить местонахождение должника }\end{array}$ & 741 & 17,7 & 22774 & 10,7 \\
\hline
\end{tabular}

Составлено по данным Инспекции Федеральной налоговой службы по Свердловскому округу г. Иркутска за период с 1 января по 31 декабря 2015 г.

320

$(43,2 \%)$

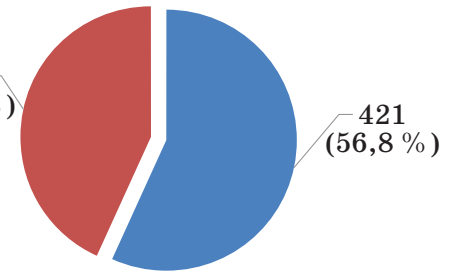

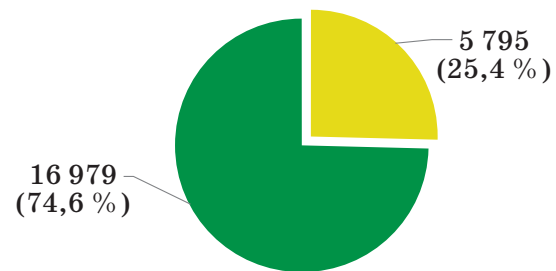
5795
$(25,4 \%)$

Возвращено постановлений ФССП по организациям, зарегистрированным по адресам жилого фонда, шт.

— Возвращено постановлений ФССП по организациям, зарегистрированным по адресам, не относящимся к жилому фонду, шт.

— Сумма возвращенных постановлений ФССП по организациям, зарегистрированным по адресам жилого фонда, тыс. р.

— Сумма возвращенных постановлений ФССП по организациям, зарегистрированным по адресам, не относящимся к жилому фонду, тыс. p.

Рис. 3. Количество и сумла возвращенных Федеральной службе судебных приставов исполнительных производств по причине невозможности определения местонахождения должников в 2015 г. по Свердловскому округу г. Иркутска

Отметим, что наибольший удельный вес в 2015 г. составили исполнительные производства, которые еще не исполнены $-69,7$ \% от общего количества должников-организаций (см. табл. 3). Самые низкие веса занимают исполнительные производства, по результатам которых денежные средства поступили в бюджет $-3,8$ \% . Данное обстоятельство является негативным фактом в деятельности ФССП. При этом 17,7 \% постановлений на сумму 22774 тыс. р. было возвращено по причине невозможности установления местонахождения должника, из них больше половины - это должники-организации, зарегистрированные на адресах жилого фонда с суммой задолженности 5795 тыс. p. (см. рис. 3). Более половины исполнительных производств возращено ФССП по причине невозможности установления местонахождения должников-организаций, зарегистрированных в жилом фонде, т. е. око-

\section{Baikal Research Journal}


ло 3 \% от общей суммы задолженности организаций уже никогда не поступит в бюджет и это только в рамках одной налоговой инспекции.

Почему же существует данная тенденция и что с ней можно сделать? Согласно п. 2 и 3 ст. 288 Гражданского кодекса РФ жилые помещения могут использоваться для проживания в них граждан. Размещение в жилом помещении каких-либо организаций допускается только в случае перевода данного помещения в статус «нежилое». На первый взгляд, указанные положения закона могут навести на мысль, что регистрация фирмы на домашнем адресе невозможна.

Однако стоит обратиться к понятию юридического адреса. Так, согласно п. 2 ст. 8 Федерального закона «О государственной регистрации юридических лиц и индивидуальных предпринимателей» от 8 августа 2001 г. № 129-ФЗ юридический адрес - это «место нахождения постоянно действующего исполнительного органа ООО (руководителя), а в случае отсутствия постоянно действующего исполнительного органа - иного органа или лица, имеющих право действовать от имени юридического лица без доверенности». Следовательно, законом разрешена регистрация ООО на домашние адреса учредителя или директора.

Стоит отметить, что регистрация организации в квартире или другом жилом помещении может быть обоснована. Так, п. 2 ст. 17 Жилищного кодекса РФ определяет, что жилое помещение может использоваться для предпринимательской деятельности проживающими в нем на законных основаниях гражданами, если это не нарушает интересы других лиц.

Осуществление многих видов деятельности (табл. 4, выделение жирным шрифтом) в жилом помещении невозможно без нарушения интересов третьих лиц. Следовательно, организации якобы осуществляют основную деятельность на адресах государственной регистрации, но выявить фактический адрес осуществления деятельности, даже через информационный ресурc https://www.sparkinterfax.ru/, не предоставляется возможным. При этом запрещающего ограничения регистрации организации на домашнем адресе не существует. На сегодняшний день это большой минус в законодательстве.

Таблица 4

Виды экономической деятельности организаций, зарегистрированных на домашних адресах, и их налоговая задолженность в Свердловском районе г. Иркутска

\begin{tabular}{|l|r|r|}
\hline \multicolumn{1}{|c|}{ Наименование ОКВЭД } & $\begin{array}{r}\text { Код } \\
\text { ОКВЭД }\end{array}$ & $\begin{array}{r}\text { Сумма задолжен- } \\
\text { ности, тыс. р. }\end{array}$ \\
\hline Строительство зданий и сооружений & $\mathbf{4 5 , 2}$ & $\mathbf{2 2 ~ 9 0 0}$ \\
\hline Производство общестроительных работ & $\mathbf{4 5 , 2 1}$ & $\mathbf{1 7 4 0 6}$ \\
\hline Лесозаготовки & $\mathbf{0 2 . 0 1 . 1}$ & $\mathbf{6 9 9 7}$ \\
\hline $\begin{array}{l}\text { Оптовая торговля лесоматериалами, строительными материалами } \\
\text { и санитарно-техническими оборудованием }\end{array}$ & $\mathbf{5 1 , 5 3}$ & \\
\hline Оптовая торговля машинами и оборудованием & 51,6 & $\mathbf{4 1 4 5}$ \\
\hline $\begin{array}{l}\text { Деятельность прочих общественных организаций, не включенных } \\
\text { в другие группировки }\end{array}$ & 91,33 & 2032 \\
\hline Распиловка и строгание древесины; пропитка древесины & $\mathbf{2 0 , 1}$ & 2558 \\
\hline Оптовая торговля металлами в первичных формах & $\mathbf{5 1 . 5 2 . 2}$ & $\mathbf{2 1 4 1}$ \\
\hline Деятельность агентств по операциям с недвижимым имуществом & 70,31 & $\mathbf{1 9 8 2}$ \\
\hline Деятельность автомобильного грузового транспорта & $\mathbf{6 0 , 2 4}$ & $\mathbf{1 6 9 3}$ \\
\hline Розничная торговля по заказам & 52,61 & $\mathbf{1 2 9 9}$ \\
\hline Оптовая торговля прочими пищевыми продуктами & 51,38 & 1259 \\
\hline Производство электромонтажных работ & 45,31 & 1254 \\
\hline Проведение расследований и обеспечение безопасности & 74,6 & 1210 \\
\hline
\end{tabular}

Составлено по данным Инспекции Федеральной налоговой службы по Свердловскому округу г. Иркутска.

\section{Baikal Research Journal}

электронный научный журнал Байкальского государственного университета 
Динамика задолженности, которую приставы возвращают взыскателям и прекращают производство согласно подп. 3 п. 1 ст. 46 Федерального закона «Об исполнительном производстве» № 229-ФЗ с формулировкой «Невозможно установить местонахождение должника и выявить наличие имущества» с каждым годом возрастает. Дальнейшее урегулирование сводится к нулю и не предоставляется возможным в силу определенных причин, так как судебные приставы в соответствии с п. 1 ст. 36 Федерального закона «Об исполнительном производстве» № 229-ФЗ не могут выявить в двухмесячный срок должника.

Таким образом, для эффективного урегулирования задолженности и применения судебными приставами полного комплекса мер в двухмесячный срок, необходимо в действующее законодательство внести поправки. Для этого следует определить перечень кодов ОКВЭД, по которым запрещается регистрация (миграция) организаций на адреса жилого фонда. Нужно внести этот перечень видов деятельности в Федеральный закон «О государственной регистрации юридических лиц и индивидуальных предпринимателей» № 129-ФЗ и ст. 17 ЗЖилищного кодекса РФ, поскольку налоговая задолженность таких организаций имеет повышательную динамику и в настоящее время ее урегулирование без имущества и денежных средств на счетах не предоставляется возможным.

Данная мера позволит снизить налоговую задолженность до $3 \%$, что в масштабах Иркутской области составит более 358 млн р. (по отношению к общей сумме налоговой задолженности в Иркутской области), а в масштабах страны - до 33724 млн р.

\section{Список использованной литературы}

1. Майбуров И. А. Налоги и налогообложение: учеб. для студентов вузов / И. А. Майбуров. - 5-е изд., перераб. и доп. - М. : Юнити-Дана, 2012. - 559 с.

2. Налоги и налогообложение / Д. Г. Черник [и др.]. - М. : Инфра-М, 2012. - 369 с.

3. Мохтари М. Эконометрический анализ неплатежей в России / М. Мохтари, С. Кейнер, В. Конторович // Экономический журнал Высшей школы экономики. -2000 . - № $1 .-$ C. $3-16$.

4. Попова Г. Л. Недоимка по налогам и сборам, пеням и налоговым санкциям регионов Центрального федерального округа: анализ динамики / Г. Л. Попова / Финансовая аналитика: проблемы и решения. - 2015. - № 20 (254). - С. 32-43.

5. Лавровский Б. Л. Налоговая задолженность: уроки кризиса (на примере регионов Сибирского федерального округа) / Б. Л. Лавровский, И. А. Мурзов, А. С. Мишина // Пространственная экономика. -2012 . - № 1. - С. 135-146.

6. Киреенко А. П. Издержки налогообложения в Российской Федерации / А. П. Киреенко, С. С. Быков. - Иркутск : Изд-во БГУЭП, 2012. - 189 с.

7. Пирогова А. В. Налоговая задолженность в условиях несостоятельности организаций : автореф. дис. ... канд. экон. наук : 08.00.10 / А. В. Пирогова. - М., 2010. - 22 с.

8. Шумяцкий Р. И. Урегулирование налоговой задолженности организаций : автореф. дис. ... канд. экон. наук : 08.00.10 / Р. И. Шумяцкий. - М., 2007. - 22 с.

9. Алиев Б. Х. Методические аспекты классификации налогоплательщиков для целей администрирования налоговой задолженности / Б. Х. Алиев, А. А. Казимагомедов, П. М. Курбанова // Фундаментальные исследования. - 2015. - № 2. - С. 3554-3558.

10. Бондарь О. А. Совокупная задолженность по налоговым обязательствам: предпосылки возникновения и проблемы ее снижения / О. А. Бондарь // Власть и управление на Востоке России. - 2011. - № 1. - С. 55-62.

11. Киреенко А. П. Издержки налогообложения в Российской Федерации / А. П. Киреенко, С. С. Быков. - Иркутск : Изд-во БГУЭП, 2012. - 189 с.

12. Адагимова Ф. Ф. Миграция налогоплательщиков - организаций как фактор роста налоговой задолженности / Ф. Ф. Адагимова // Финансы и кредит. - 2011. - № 1. - С. 14-20.

13. Кирина Л. С. Снижение налоговых рисков государства при регистрации фирм-однодневок / Л. С. Кирина, Н. А. Горохова, А. В. Александров // Экономика. Налоги. Право. 2013. - № 4. - C. 87-90.

\section{Baikal Research Journal}

электронный научный журнал Байкальского государственного университета 


\section{References}

1. Mayburov I. A. (ed.). Nalogi i nalogooblozhenie [Taxes and Taxation]. $5^{\text {th }}$ ed. Moscow, Yuniti-Dana Publ., 2012. 559 p.

2. Chernik D. G.et al. Nalogi i nalogooblozhenie [Taxes and Taxation]. Moscow, Infra-M Publ., 2012. 369 p.

3. Mokhtari M., Keiner S., Kontorovich V. Econometric analysis of arrears in Russia. Eko nomicheskii zhurnal Vysshei shkoly ekonomiki = Higher School of Economics. Economic Journal, 2000, no. 1, pp. 3-1. (In Russian).

4. Popova G. L. Arrear in taxes, duties and fees, fines and tax sanctions in the regions of the Central Federal District: analysis of dynamics. Finansovaya analitika: problemy $i$ resheniya $=$ Financial Analytics: Science and Experience, 2015, no. 20 (254), pp. 32-43. (In Russian).

5. Lavrovsky B. L., Murzov I. A., Mishina A. S. Tax liabilities: lessons of the crisis (using the example of the Siberian Federal District). Prostranstvennaya ekonomika = Spatial Economics, 2012, no. 1, pp. 135-146. (In Russian).

6. Kireyenko A. P., Bykov S. S. Izderzhki nalogooblozheniya v Rossiiskoi Federatsii [Expenses of Taxation in the Russian Federation]. Irkutsk, Baikal State University of Economics and Law Publ., 2012. 190 p.

7. Pirogova A. V. Nalogovaya zadolzhennost'v usloviyakh nesostoyatel'nosti organizatsii. Avtoref. Kand. Diss. [Tax liabilities in terms of organizations' insolvency. Cand. Diss. Thesis]. Moscow, 2010.22 p.

8. Shumyatsky R. I. Uregulirovanie nalogovoi zadolzhennosti organizatsii. Avtoref. Kand. Diss. [Regulating tax liabilities of organizations. Cand. Diss. Thesis]. Moscow, 2007. 22 p.

9. Aliyev B. Kh., Kazimagomedov A. A., Kurbanova P. M. Methodical aspects of taxpayers' classification for purposes of administrating tax liabilities. Fundamental'nye issledovaniya $=$ Fundamental Investigations, 2015, no. 2, pp. 3554-3558. (In Russian).

10. Bondar' O. A. Aggregate indebtedness in tax liabilities: prerequisites of genesis and problems of its reduction. Vlast' $i$ upravlenie na Vostoke Rossii = Power and Administration in the East of Russia, 2011, no. 1, pp. 55-62. (In Russian).

11. Adagimova F. F. Migration of taxpayers-organizations as a growth factor for tax liabilities. Finansy $i$ kredit = Finance and Credit, 2011, no. 1, pp. 14-20. (In Russian).

12. Kirina L. S., Gorokhova N. A., Aleksandrov A. V. Reducing governmental tax risks in registering phoenix operations. Ekonomika. Nalogi. Pravo = Economy. Taxes. Law, 2013, no. 4, pp. 87-90. (In Russian).

\section{Информация об авторах}

Завьялова Екатерина Олеговна - аспирант, ассистент, кафедра налогов и таможенного дела, Институт национальной и экономической безопасности, Байкальский государственный университет, 664003, г. Иркутск, ул. Ленина, 11, e-mail: nalog.audit@mail.ru.

Завьялов Виктор Игоревич - магистрант, кафедра налогов и таможенного дела, Институт национальной и экономической безопасности, Байкальский государственный университет, 664003, г. Иркутск, ул. Ленина, 11, e-mail: nalog.audit@mail.ru.

\section{Authors}

Ekaterina O. Zavyalova - PhD Student, Teaching Assistant, Chair of Taxes and Customs, Institute of National and Economic Security, Baikal State University, 11 Lenin St., 664003, Irkutsk, Russian Federation; e-mail: nalog.audit@mail.ru.

Viktor I. Zavyalov - Master Degree Student, Chair of Taxes and Customs, Institute of National and Economic Security, Baikal State University, 11 Lenin St., 664003, Irkutsk, Russian Federation; e-mail: nalog.audit@mail.ru.

\section{Библиографическое описание статьи}

Завьялова Е. О. Почему регистрация организаций в жилом фонде препятствует увеличению доходов бюджета? / Е. О. Завьялова, В. И. Завьялов // Baikal Research Journal. 2016. — T. 7, № 5. — DOI : 10.17150/2411-6262.2016.7(5).5.

\section{Reference to article}

Zavyalova E. O., Zavyalov V. I. Why registration of organizations in the housing stock prevents increase in budget revenues. Baikal Research Journal, 2016, vol. 7, no. 5. DOI : 10.17150/2411-6262.2016.7(5).5. (In Russian).

\section{Baikal Research Journal}

